\title{
A conversation with Alexander Rudensky
}

A lexander "Sasha" Rudensky from the Memorial Sloan Kettering Cancer Center has had a profound impact in the world of immunology through his study of regulatory $\mathrm{T}$ cells. In a series of landmark studies, he defined the factors that identify and differentiate these cells. He's demonstrated the critical roles that regulatory $\mathrm{T}$ cells play in autoimmunity, tolerance, allergy, infections, and cancer. The full interview, wherein Rudensky (Figure 1) talks about being a better chemist than dancer and how he bribes his trainees can be seen on the JCI website at http://www.jci.org/kiosk/cgm.

JCI: Where did you grow up?

Rudensky: I was born in Moscow in the very beginning of Khrushchev's Spring (or Thaw) in 1956, the pivotal year when Khrushchev denounced the crimes committed by Stalin. My father had enrolled in the army, ending up in artillery school at the age of 17. After graduation, he brought ammunition to fronts as a junior officer in the Soviet Army. After the war, he ended up as an army officer working in the Ministry of Interior, dealing with prisoners of war. After the purge of Jews from the Ministry of Interior and other state security-affiliated entities, he ended up going back to school to become an engineer. After he finished his technical studies, he worked in one of many so-called PO boxes or secret R\&D centers, dealing with development of weapons and missiles. He was specifically involved in developing gyroscopes. He later became a bureaucrat in the Soviet Academy of Sciences. On the side, he edited books on mathematics and physics, focusing on space flight, missiles, and rockets. My mother was 16 when the war started. Her family was evacuated from Moscow and ended up in the Ural Mountains, where my grandfather died and left my grandmother and my mother and my uncle alone. They came back in 1944 to Moscow, where she later graduated from Moscow University Law School. That was in the early ' 50 s, the time of the Doctors' Plot, and not necessarily the best time for a young, Jewish woman to practice law. She ended up getting

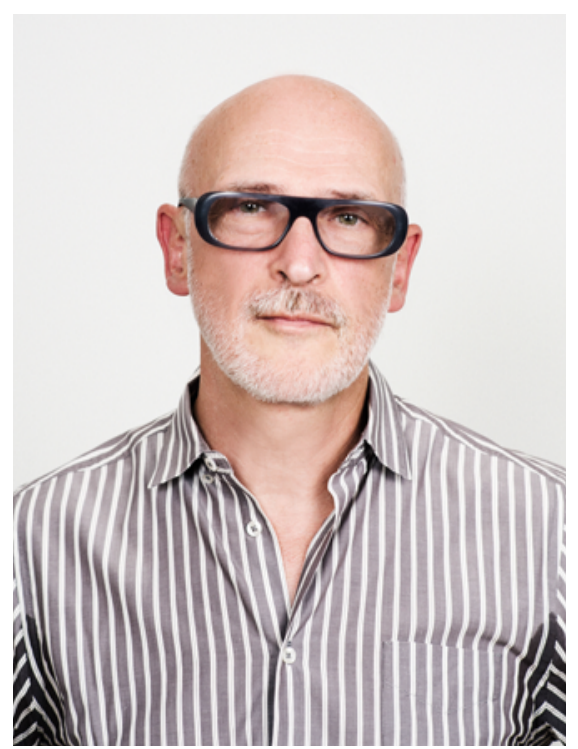

Figure 1. Sasha Rudensky in New York on July 21, 2016. Image credit: Alexey Levchenko.

a second education and became a teacher of Russian literature.

JCI: Were you encouraged in Russian literature and mathematics and science?

Rudensky: Science was greatly respected in the Soviet Union. I grew up at the time where fascination with science was widespread, at least in the Soviet Union. I remember being not quite five years old when I heard on the radio a report of the first space flight of Yuri Gagarin. I remember the shift in fascination from astronomy to physics to biology, with some delay, among Soviet schoolchildren and the public at large.

I imagined I would become a mathematician. I came in second in a regional Mathematics Olympiad, but I think that was early on, and I figured out that I wasn't as good at math as I thought I was. I became interested in botany; I went to the Botanical Garden of the Academy of Sciences and tried to volunteer there in sixth or seventh grade. Then I got interested in chemistry.

JCI: I read a vignette that you and a friend started making fireworks when you got interested in chemistry.

Rudensky: They were not even fire- works, just explosives. Anyone could buy chemicals from these stores selling chemical reagents in Moscow. We collected our pocket money from what we were getting for school breakfast or lunch and bought reagents to make explosives and also colorful and sometimes stinky chemical potions in our apartments.

I then enrolled in evening chemistry school at the Faculty of Chemistry of Moscow State University, and that was pretty amazing because graduate students and professors of the Faculty of Chemistry were teaching high schoolers in the evening. I loved organic synthesis, loved all the amazing glassware that was involved in it. By the time I finished high school, I was starting to find chemistry a bit dry and started thinking of biochemistry instead. I entered the Department of Biochemistry at the Second Medical School in Moscow.

JCI: What led to an immunology $\mathrm{PhD}$ ?

Rudensky: Towards the middle of my studies at university, I was finding biochemistry a bit dry. I worked one summer in an immunology lab, and I got in touch with the head of an immunochemistry lab in one of the premier research institutes of the Academy of Medical Sciences in Moscow. I started working in the evenings, summers, and weekends and did my master's thesis in immunochemistry. My project mapped interaction sites of staphylococcal protein $\mathrm{A}$ with immunoglobulin molecule using enzymatic methods and protein fractionation. It was essentially biochemistry, but focused on immune molecules.

After I finished my master's degree, my mentor Alexander Kulberg wanted me to stay for graduate studies. But I couldn't, since there were unwritten limits for Jews to get admitted at some research institutions and universities. In hindsight, it was very fortunate because I ended up working with Vitalij Yurin, one of the best molecular immunologists in the Soviet Union, and doing more mainstream immunology. The focus of my $\mathrm{PhD}$ was antigen presentation and processing of molecules synthesized by $\mathrm{B}$ lymphocytes for $\mathrm{T}$ cell recognition. The theme might seem a bit obscure, but at that time, we were fascinated with the mystery of the $\mathrm{T}$ cell receptor: how it works, how it 
recognizes antigen. I spent my summer after graduation from the university sitting with my daughter, who was born on the day of graduation, reading a pile of papers on this topic from Nature, Cell, Science, and review articles from a Cold Spring Harbor meeting. These readings were my first exposure to English; my first foreign language was German. I found it all absolutely fascinating.

JCI: At some point, you got to go to Germany to present your work.

Rudensky: There was an enormous change that occurred in the Soviet Union between 1987 and 1989 - the Gorbachev years. I never thought that I would be able to go anywhere to cross the border of the Soviet Union unless we decided to immigrate to Israel or the US. But then the borders opened. So my trip to West Berlin, just before the fall of the Berlin Wall in 1989, was striking. That was my first trip to the West, other than in 1986 when I visited Bulgaria as a part of a business trip where my passport was stolen and a KGB officer in charge told me that my passport was in the hands of the CIA and I would never cross the border or even come close to the border of the Soviet Union again. Gorbachev was already in power. So I was convinced that it would never happen in my lifetime. But life is full of surprises.

I went to the Congress and also I visited the Max Planck Institute in Freiburg - I was invited by Michael Reth, whom I met when he had visited Moscow. As a result, I was invited by Georges Köhler [who shared the 1984 Nobel Prize] to work in his lab. I thought we would go for a couple of years, but for some bizarre, bureaucratic reasons, I was unable to get a German visa to go with my family to Germany to work for Georges.

JCI: At this point, you had four children?

Rudensky: Number four was on his way, so we wanted to go before our youngest son was born. I wrote a letter to Charlie Janeway, whose writing and work I admired, but whom I had never met. I then called him, and the first thing he said was, "When do you want to come?" - which was stunning. That was in November, and we came at the end of February.

I was very lucky and very grateful to Charlie for taking a risk that I don't know whether I would ever take, for inviting someone he never met. He may have seen a few papers that I published out of Moscow in the European Journal of Immunology, which was unusual for a Soviet immunologist. His fas- cination with generating new concepts and new ideas, which were sometimes wrong, but many times, were so right and profound ... these ideas changed modern immunology's thinking about the basic principles of the way the immune system operates.

JCI: You then moved to Seattle for your first academic position. Why stay in the US?

Rudensky: Our fears of potential oppression did materialize: there was a coup, and the Soviet Union ceased to exist; 1992, in post-Soviet Russia, was an extremely difficult time, where people didn't have food, and the direction the country was going was not particularly appealing. So it's not that we decided that we'd stay permanently. The realization that my family was going to stay in the US permanently came much later.

As for Seattle, one day, Charlie received a letter from Roger Perlmutter, who was then chairman of the newly established Department of Immunology at the University of Washington. Roger was soliciting applications for assistant professors. Charlie gave me this letter and told Roger that I would be a good candidate. It was my first interview. I was not inclined to leave Charlie's lab so soon, but I got an offer and the small, young Department of Immunology at the University of Washington was amazing.

\section{JCI: How has your science pivoted?}

Rudensky: The field of antigen processing and presentation peaked in terms of exciting biological questions in the late '80s/early '90s, and I felt that from the perspective of biological understanding, the field of antigen presentation was becoming increasingly mature. I really wanted to address more biologically exciting questions. I had a fantastic postdoctoral fellow [Marc Gavin] who joined my lab at the time, and he was interested in regulatory $\mathrm{T}$ cells that were characterized several years before by Shimon Sakaguchi, who reported cell surface markers of those cells. I thought, perhaps naively, that we would be able to identify their specificity and to find answers to many questions related to biology of the cells through mechanistic insights.

So that's where we started, and it was Marc's work that convinced us that regulatory $\mathrm{T}$ cells represented a distinct lineage of cellular differentiation. It was exciting because the phenomenon of regulation of activity of other cells of the immune system by a dedicated population of cells represented an unparalleled principle of negative regulation in biology.

JCI: Is there anything that regulatory $\mathrm{T}$ cells can't do? For the last 20 years, you've elucidated their involvement in maternal fetal tolerance, infection, and autoimmunity, now within cancer and metabolic diseases, the communication with the microbiome.

Rudensky: There is probably more. What we don't know is the way different cell types belonging to the immune system, connective tissue, parenchymal cells, and neurons interact with each other in a complex environment of an organ and tissue during organ development, during changes in physiological function, or in disease. Cells of the immune system act as amplifiers, facilitators, or decelerators of processes, or in the case of regulatory $\mathrm{T}$ cells, negative regulators, and are placed at the critical nodes of these complex cellular networks that we poorly understand.

JCI: Your approach to mentoring?

Rudensky: My approach is to be a midwife. I try to help my trainees, but not to intervene with their own thinking and interfere with their growth. I try to give them as much intellectual and experimental space as they can handle. I believe that independent thinking, ability to take initiative, and to think big are key for their success.

JCI: One of your former trainees specifically mentioned the fact that you are better read than any of the rest of them, better travelled, more cultured. He mentioned your love of opera. Clearly your dedication to science has not kept you from a passion for other interests.

Rudensky: This is, to a large degree, baggage from my years in the Soviet Union, because scientific life there was less intense in terms of demands on time. Even if you didn't spend all your time in the lab, you could succeed on some scale, but also read philosophy, poetry, history books, or become interested in Indian architecture or Chinese history. I think the intensity of professional life in the US in particular puts so much pressure on practicing scientists, especially young scientists, that there is a danger of people growing more one dimensional.

JCI: If you could not be a scientist, what other career do you think would have kept you so dedicated?

Rudensky: I'd be a counselor. I like people.

Ushma S. Neill 